\title{
BRPKM
}

Buletin Riset Psikologi dan Kesehatan Mental

http://e-journal.unair.ac.id/index.php/BRPKM

e-ISSN: 2776-1851

ARTIKEL PENELITIAN

\section{Gambaran Anger Issues, Coping Stress, dan Risiko PTSD pada Taruna Marinir AAL Selama Dikko}

\author{
ALMIRA NADYA YASMINE \& AFIF KURNIAWAN* \\ Fakultas Psikologi Universitas Airlangga
}

\begin{abstract}
ABSTRAK
Anger issues sebagai permasalahan dalam regulasi emosi kerap dialami oleh taruna dari institusi kemiliteran di Indonesia. Implementasi anger issues di kalangan taruna dewasa ini berupa kasus penganiayaan kepada junior. Korps Marinir diketahui sebagai penjurusan di Akademi Angkatan Laut yang memiliki intensitas latihan fisik tertinggi dan satu-satunya korps yang mengikuti Pendidikan Komando (Dikko). Penelitian bertujuan mengetahui gambaran anger issues, strategi koping stres, dan menguraikan risiko PTSD pada taruna Korps Marinir Akademi Angkatan Laut pasca menempuh Pendidikan Komando. Penelitian menggunakan pendekatan kualitatif dengan metode studi kasus intrinsik. Wawancara mendalam dan kuesioner skrining PTSD sebagai metode pengambilan data. Pengorganisasian dan analisis data menggunakan analisis tematik dengan pendekatan theory driven. Triangulasi data menggunakan member check. Gambaran anger issues dan strategi koping kedua subjek selama Dikko berbeda, dan keduanya mengalami trauma pasca Dikko namun dengan derajat keparahan yang berbeda. Derajat keparahan trauma yang dialami bergantung pada tingkat resiliensi atau faktor protektif individu.
\end{abstract}

Kata kunci: anger issues, marinir, pendidikan komando, PTSD, stres

\begin{abstract}
Anger issues as problems are often experienced by cadets from military institutions in Indonesia. The implementation of anger issues among cadets recently is in the form of abuse to junior personnel. The Marine Corps is known as a major in the Naval Academy which has the highest intensity of physical training and is the only corps that participates in Commando Education (Dikko). This study aims to describe anger issues, coping strategies, and the risk of PTSD in Marine Corps cadets post Commando Education. This research uses a qualitative approach with an intrinsic case study method. In-depth interviews and PTSD screening questionnaires were conducted in data collection. Organizing and analyzing the data was carried out using thematic analysis with a theory driven approach. Data triangulation was carried out with membercheck. The description of anger issues and coping strategies of the two subjects during Dikko was different, and both experienced post-Dikko trauma but with different degrees of severity. The severity of the trauma experienced depends on the level of resilience or individual protective factors.
\end{abstract}

Keywords: anger issues, commando education, marines, PTSD, stress

Buletin Penelitian Psikologi dan Kesehatan Mental (BRPKM), 2021, Vol. 1(1), 985-1002

*Alamat korespondensi: Fakultas Psikologi Universitas Airlangga, Kampus B Universitas Airlangga Jalan Airlangga 4-6 Surabaya 60286. Surel: afif.kurniawan@psikologi.unair.ac.id 
sehingga penggunaan, distribusi, reproduksi dalam media apapun atas artikel ini tidak dibatasi, selama sumber aslinya disitir dengan baik.

\section{PENDAHULUAN}

Dewasa ini, marak ditemukan kasus kekerasan dan penganiayaan yang terjadi di kalangan instansi pendidikan militer di Indonesia, dengan korban yang beragam, mulai dari mengalami cedera ringan, berat, hingga meninggal dunia. Meskipun secara umum dianggap sebagai emosi negatif, namun dalam konteks militer, reaksi kemarahan sangat penting karena hubungannya dengan mengatasi perilaku tidak etis (Wilk dkk., 2013). Namun tak sedikit pula oknum yang memiliki motif lain disamping sekedar menegur. Seperti yang terjadi tahun 2017 silam, seorang taruna tingkat II Akademi Kepolisian, Muhammad Adam, tewas dianiaya oleh 13 taruna senior tingkat III yang awalnya bermaksud menegur beberapa kesalahan etika antara senior dan junior di dalam kampus (Atriana \& Pratama, 2019).

Kasus tanpa korban jiwa baru baru ini terjadi di Akademi Militer tahun 2019 lalu, kasus tindak penganiayaan terhadap taruna tingkat I disertai aksi pencurian yang dilakukan oleh dua orang oknum taruna tingkat III dan IV (Putra, 2019). Terakhir dari Akademi Angkatan Laut, terjadi kasus penganiayaan di bulan Desember 2018 yang berujung kematian antara terdakwa, taruna tingkat III, dengan korban seorang Sersan. Terdakwa hendak menegur untuk mengingatkan kesalahan korban dengan cara memukul kedua paha bagian belakang dan di bagian perut berkali-kali hingga meninggal dunia (Putusan Terbaru Dilmil III-12 Surabaya, 2019). Uniknya, segala macam tindakan fisik dengan tujuan pendisiplinan diperbolehkan di instansi pendidikan kemiliteran, termasuk Akademi Angkatan Laut. Tentunya pendisiplinan tersebut harus sesuai dengan prosedur dan standar operasional seperti yang dicantumkan dalam Peraturan Khusus Taruna Akademi Angkatan Laut (Persustar AAL) tahun 2019.

Dari serangkaian contoh kasus penganiayaan di atas, dapat disimpulkan bahwa amarah memainkan peran penting dalam kehidupan sehari-hari. Kemarahan adalah salah satu dari serangkaian keadaan emosional dan afektif yang menjadi masalah bagi individu dan merupakan alasan untuk mencari bantuan terapeutik (Howels \& Day, 2003). Anger issues adalah sebuah permasalahan terkait emosi marah dimana individu memiliki kesulitan dalam mengontrol amarah dan kemudian diimplementasikan dalam bentuk ucapan atau perbuatan agresif yang nantinya akan disesali (Legg, 2019). Pada dasarnya kemarahan tidak dianggap sebagai gangguan dan merupakan emosi normal yang dialami manusia. Tetapi ketika kemarahan tersebut berlebihan, tak terkendali, dan tidak sesuai takaran, maka patut dicurigai sebagai gejala dari beberapa kondisi kesehatan mental (Legg, 2019). Individu dengan trait anger yang tinggi diketahui cenderung berperilaku agresif mengikuti provokasi (Wilkowski \& Robinson, 2010). Selain itu, individu dengan trait anger tinggi juga cenderung menganggap situasi berbahaya dan kurang mampu mengendalikan pikiran serta perasaan bermusuhan (Veenstra dkk., 2018).

Selain rentan berperilaku agresif, para tentara juga rentan terhadap stres. Tidak peduli seberapa terlatih fisik dan mentalnya, tentara sebagai manusia tetap rentan terhadap stres dan cedera (Sharma \& Sharma, 2012). Tentunya para taruna memiliki beberapa periode stres selama pendidikan. Banyak stresor pekerjaan di lingkungan militer, seperti kecepatan kerja, kontrol, pengawasan, jam kerja yang panjang, serta kerja shift (Bogg \& Cooper, 1995). Di samping stressor pekerjaan, lingkungan militer juga memiliki pemicu stres tambahan, seperti risiko cedera atau kematian (Castro \& Adler, 1999 dalam Dolan \& Ender, 2008) serta stres dalam hal akademik. Korps Marinir ialah salah satu dari lima korps di Akademi 
Angkatan Laut yang memiliki kualifikasi khusus dan harus dikuasai selama masa pendidikan, antara lain memiliki kemampuan sebagai pasukan dengan kualifikasi terjun para dasar dan dasar komando, melaksanakan tugas sebagai Komandan Peleton Infanteri, serta memiliki bekal ilmu pertahanan di bidang peperangan darat untuk pengembangan karier sebagai kader pemimpin (Akademi Angkatan Laut, 2019). Kualifikasi tercantum dapat berpotensi menjadi stressor akademik bagi taruna korps Marinir.

Lalu bagaimana dengan stres yang dialami oleh taruna yang memiliki anger issues atau trait anger? Apakah memiliki kesamaan strategi koping dengan taruna tanpa gangguan? Individu yang memiliki sifat marah atau temperamen yang tinggi, mengalami stres yang lebih parah dan cenderung mengatasinya (koping) dengan cara yang buruk (Maan Diong dkk., 2005). Jadi, individu dengan amarah tinggi tidak hanya menanggapi situasi stres dengan reaktivitas yang lebih besar, tetapi mereka juga menciptakan situasi yang lebih membuat stres untuk diri sendiri. Hal ini terjadi karena individu yang memiliki kemarahan dan permusuhan (hostility) tinggi, cenderung menimbulkan reaksi yang sama dari orang lain, sehingga meningkatkan stres lingkungan interpersonal mereka sendiri. Tingkat ekspresi kemarahan yang tinggi dikaitkan dengan jarangnya penggunaan strategi koping positif, seperti secara aktif mengutarakan masalah (Diong dan Bishop, 1999; Maan Diong dkk., 2005).

Diketahui proses adaptasi taruna terhadap perubahan berbagai kegiatan di akademi juga dapat menjadi salah satu stressor dalam lingkungan militer. Lattek Pendidikan Komando (Dikko) merupakan salah satu program latihan bagi para Taruna Tingkat III Korps Marinir yang telah ditetapkan dalam kurikulum pendidikan dan program pelaksanana pendidikan AAL (Admin Puspen TNI, 2020). Dikko bertujuan untuk membekali dan melatih siswa agar memiliki kemampuan dan keterampilan tentang taktik dan teknik Pasukan Komando sebagai bekal dalam kedinasan di Satuan Marinir dan TNI AL pada umumnya (Kodiklatal TNI AL, 2018). Tahap latihan yang dijalani meliputi tahap Dasar Komando, tahap Komando Laut, tahap Komando Hutan, tahap Gerilya Lawan Gerilya di daerah latihan Situbondo, Banyuwangi dan Lumajang, serta diakhiri dengan tahap lintas medan, yaitu peserta akan berjalan kaki dari Banyuwangi ke Surabaya dengan menempuh jarak $369 \mathrm{~km}$. Semua materi latihan tersebut harus dilaksanakan sebagai syarat untuk mendapatkan Brevet Komando dan Baret Ungu, Baret kehormatan dan kebanggaan prajurit Korps Marinir (Kodiklatal TNI AL, 2018).

Salah satu contoh rangkaian kegiatan Dikko yang berpotensi menyebabkan stres akut dan mengancam jiwa ialah lattek dopper. Dopper merupakan rangkaian dalam tahap Pendidikan Komando yang bertujuan untuk memberikan pengalaman dan keterampilan bergerak di bawah lintasan tembakan peluru tajam sehingga siswa memiliki keyakinan, keberanian, dan kemampuan untuk bergerak menuju sasaran di bawah lintasan tembakan peluru tajam. Lattek ini menggunakan peluru tajam dengan resiko yang sangat tinggi (Kodiklatal TNI AL, 2020). Berbagai kegiatan Dikko diketahui berpotensi menyebabkan stres akut dan mengancam jiwa, namun apakah selain itu juga berpotensi menimbulkan trauma dan stres pasca trauma bagi taruna dengan anger issues? Dalam penelitian ini penulis berharap dapat menemukan jawabannya.

Gangguan stres pascatrauma (PTSD) dapat berkembang setelah seseorang menyaksikan atau mengalami peristiwa traumatis, seperti bencana alam, pertempuran, atau serangan pribadi yang disertai kekerasan (Phillips dkk., 2010). Beberapa bukti menunjukkan bahwa dalam subset anggota tentara yang kembali, gejala stres pasca trauma (PTS) terus meningkat dan mengalami keparahan selama beberapa bulan dan tahun setelah kembali dari medan pertempuran (Grieger dkk., 2006 dalam Orcutt, dkk., 2004). Fitur penting dari gangguan stres pascatrauma adalah pengembangan gejala karakteristik berupa paparan satu atau lebih peristiwa traumatis (Diagnostic and Statistical Manual of Mental Disorder V, 2013). Meskipun tidak semua orang yang mengalami peristiwa traumatis akan 
mengalami PTSD, beberapa faktor termasuk intensitas trauma dan kedekatan dengan peristiwa dapat meningkatkan kecenderungan seseorang untuk mengembangkan gangguan tersebut (Phillips dkk., 2010).

Di antara anggota militer, paparan pertempuran dilaporkan sebagai prediktor terkuat dari PTSD (Phillips dkk., 2010). Bukti penelitian telah terkumpul yang menunjukkan efek buruk dari pertempuran pada kesehatan mental personel militer, terutama gangguan stres pasca-trauma (PTSD) dan penyalahgunaan alkohol (MacManus dkk., 2015). Terlepas dari peristiwa traumatis itu sendiri, faktor risiko berkembangnya PTSD diantara lain usia yang relatif belia saat terpapar trauma, status sosial ekonomi yang rendah, riwayat penyakit kejiwaan dalam keluarga, penyerangan sebelumnya, kesulitan di masa kanak-kanak, jenis kelamin perempuan, ras minoritas, dan kurangnya dukungan sosial (Phillips dkk., 2010). Tujuan yang ingin dicapai dari penelitian ini adalah untuk mengetahui gambaran secara mendalam mengenai anger issues dan koping stres taruna Korps Marinir Akademi Angkatan Laut saat menempuh Pendidikan Komando serta risiko terpapar PTSD, juga memberikan psikoedukasi kepada masyarakat dan instansi pendidikan kemiliteran di Indonesia terkait fenomena yang terjadi, sehingga dapat meningkatkan awareness akan kesehatan psikologis para taruna.

\section{METODE}

\section{Desain Penelitian}

Pada penelitian ini penulis menggunakan metode penelitian kualitatif. Tipe penelitian yang digunakan adalah studi kasus intrinsik yang dipilih karena ketertarikan atau kepedulian pada suatu kasus khusus. Penelitian dilakukan untuk memahami secara utuh kasus tersebut, tanpa harus dimaksudkan untuk menghasilkan konsep-konsep, teori, ataupun menggeneralisasikan. Teknik pengambilan data yang digunakan dalam penelitian adalah wawancara mendalam dan kuesioner skrining gejala PTSD. Dalam hal ini, peneliti menggunakan wawancara semi-terstruktur yang termasuk kedalam kategori in-depth interview dimana peneliti akan berusaha untuk menemukan permasalahan secara lebih terbuka dan pihak informan akan diminta pendapat maupun ide. Desain ini diharapkan dapat menjawab pertanyaan-pertanyaan penelitian, yaitu bagaimana gambaran anger issues, strategi coping stress, dan risiko Posttraumatic Stress Disorder pada taruna korps Marinir Akademi Angkatan Laut yang menempuh Pendidikan Komando?

\section{Partisipan}

Penulis menggunakan criterion based atau teknik purposive sebagai teknik untuk menentukan partisipan. Criterion based atau teknik purposive dipilih karena memiliki fitur atau kriteria tertentu yang akan memungkinkan eksplorasi dan pemahaman rinci tentang tema yang sesuai dengan masalah dan tujuan penelitian. Partisipan penelitian merupakan partisipan utama berjumlah 2 (dua) orang dan keduanya merupakan taruna aktif Korps Marinir, Akademi Angkatan Laut dengan kriteria memiliki anger issues dan telah menempuh Pendidikan Komando (DIKKO). Kriteria-kriteria tersebut juga dicantumkan dalam kuesioner skrining gejala PTSD yang dibuat dalam bentuk google form beserta persetujuan informed consent.

\section{Strategi Pengumpulan Data}

Menurut Poerwandari (2005), wawancara bertujuan untuk memperoleh pengetahuan mengenai makna-makna subjektif yang dipahami individu dan berhubungan dengan topik yang akan diteliti dan 
bermaksud melakukan eksplorasi terhadap isu tersebut. Wawancara dengan pedoman umum adalah proses wawancara yang dilakukan dengan membuat pedoman wawancara yang bersifat umum. Pedoman wawancara berfungsi sebagai pengingat bagi penulis mengenai topik-topik yang harus digali, sekaligus menjadi daftar pengecek apakah aspek-aspek tersebut sudah ditanyakan atau dibahas (Poerwandari, 2005). Sehubungan dengan situasi pandemi, wawancara dilakukan secara daring melalui video meeting dari aplikasi Zoom sebanyak 4 (empat) sesi pada hari dan tanggal yang telah disepakati penulis dan partisipan.

Prinsip-prinsip informed consent seperti anonimitas dan kerahasiaan yang sesuai dengan Kode Etik Psikologi pun dipatuhi sepanjang proses pengumpulan dan analisis data. Partisipasi sepenuhnya bersifat sukarela dan partisipan diberikan informasi adanya hak yang akan mereka dapatkan, yakni partisipan diperbolehkan untuk mundur pada setiap tahap penelitian. Penelitian berbasis wawancara memiliki sifat pribadi sehingga partisipan memiliki hak untuk tidak menjawab pertanyaan. Semua partisipan dirujuk dengan nama inisial yang sudah disepakati.

\section{Analisis Data}

Teknik analisis data dalam penelitian ini adalah analisis tematik. Analisis tematik dibagi menjadi tiga jenis, yaitu theory driven, prior research dan data driven (Boyatzis, 1998). Analisis theory driven merupakan proses dimana pengkodean yang dilakukan pada transkripsi berasal dari teori-teori yang ada. Proses memberikan kode dapat disebut dengan proses koding, di mana proses ini membantu mengorganisasikan data secara sistematis. Penulis mengawali proses koding dengan mengumpulkan data mentah dari kedua subjek, kemudian mengaitkan dengan teori dan mengolahnya menjadi kodekode penelitian. Dalam melakukan proses koding, penulis membangun tema dan kode dari data mentah, kemudian melakukan pengelompokan, hingga akhirnya menarik sintesa tertentu sesuai dengan tujuan penelitian.

Selanjutnya untuk pemantapan kredibilitas, penulis menggunakan membercheck. Membercheck merupakan proses untuk memastikan ulang data yang didapat dengan pemberi data (partisipan). Tujuan dilakukannya membercheck yaitu agar informasi yang diperoleh dalam laporan penelitian memiliki kesesuaian dengan apa yang dimaksudkan oleh sumber data atau partisipan (Mekarisce, 2020). Mekanismenya dapat dilakukan secara individual, yaitu peneliti menemui partisipan atau bertemu dalam forum diskusi kelompok. Pada proses ini data dapat ditambah, dikurangi, ataupun ditolak oleh partisipan hingga diperolehnya kesepakatan bersama, dapat berupa dokumen yang telah ditanda-tangani (Sugiyono, 2017 dalam Mekarisce, 2020). Apabila partisipan menyepakati hasil data dari peneliti, maka dianggap valid dan penelitian dapat dipercaya. Apabila partisipan tidak menyetujuinya maka peneliti harus mengecek ulang dan mengubah penelitian tersebut (Sugiyono, 2010).

\section{HASIL PENELITIAN}

\section{Penyebab Anger Issues}

Partisipan 1 (PR) mengaku bahwa dirinya sudah memiliki kesulitan mengontrol amarah sejak SMP. Menurutnya hal ini disebabkan oleh pribadi PR yang suka memendam amarah (anger suppression) dan kepemilikan trait anger yang tinggi. Sehingga pada saat kesal, ia tak segan-segan melampiaskan semua kemarahan yang selama ini dipendam. Selain anger suppression, partisipan PR mengatakan bahwa perilaku kasarnya juga didukung oleh faktor lingkungan di AAL. Reinforcement atau penguatan dalam bentuk dukungan dan pujian dari para senior membuat PR berpikir bahwa tindakan agresifnya benar, 
sehingga ia berintensi untuk terus mengulang perilaku tersebut. Lain halnya dengan PR, anger issues partisipan 2 (AT) dilatarbelakangi oleh trauma masa kanak yang berkaitan dengan kekerasan dalam keluarga yang diikuti dengan proses imitasi atau hasil belajar, serta permasalaan kelekatan (attachment). Diakui oleh AT, bahwa kekerasan yang ia terima di masa kanak menjadi penyebab dirinya memiliki kepribadian temperamental dengan trait anger yang tinggi. Begitupula dengan kelekatan (attachment) serta hubungan interpersonal antara partisipan dengan orang tua yang kurang baik dan dikategorikan kelekatan anxious-ambivalent (insecure). Selain itu faktor lingkungan turut berperan, dimana Akademi Angkatan Laut sebagai institusi pendidikan kemiliteran, memperbolekan pendisiplinan taruna berupa tindakan dan perilaku kekerasan antar individu (senior-junior) selama masih dalam batas wajar dan sesuai dengan Peraturan Khusus Taruna (Persustar), sehingga perilaku agresif dan anger issues partisipan AT diperkuat (reinforced). Tidak jarang AT menyiksa junior karena tuntutan dari senior guna mendapatkan respect dari junior-juniornya.

\section{Gambaran Anger Issues Selama Dikko}

Pemicu kemarahan selama Dikko berasal dari para anggota peleton. Menurut kedua partisipan, mayoritas anggota cenderung lamban dan tak patuh pada perintah dari atasan (Komandan Peleton). Cara yang dilakukan dalam menyikapi perilaku anggota yang berulah adalah dengan menggunakan agresi fisik dan verbal (ancaman), antara lain pukulan dan tamparan. Tindakan tersebut dilakukan dengan tangan kosong, tanpa bantuan alat. Partisipan merasa harus melakukan tindakan tersebut dikarenakan para anggota yang terlampau sulit diberi teguran secara halus. Beberapa perubahan perilaku yang dirasakan partisipan PR ketika dalam keadaan marah adalah perilaku membabi buta, tidak terkendali, minim empati, dan asal menghantam siapapun yang menurutnya salah. Bahkan ketika teman-temannya menahan pun, PR tak menghiraukan dan malah semakin berapi-api. Sementara untuk reaksi fisiologis ialah peningkatan detak jantung yang intens.

Selama Dikko, partisipan PR lebih mengedepankan rasa ibanya kepada anggota. Ia merasa beruntung sudah mendapatkan teguran sebelumnya melalui keterlibatan dalam sebuah kasus, karena jika belum, mungkin ia akan tetap brutal seperti dulu. PR mengaku sudah belajar untuk lebih mengontrol emosinya, meskipun untuk beberapa persoalan masih sulit untuk legowo, terlebih jika hal tersebut merugikan dirinya. Cara yang dilakukan PR dalam mengontrol dan menahan emosinya adalah dengan menjauhi sumber kemarahan serta mengalihkan perhatiannya dengan mencari kesibukan. Sedikit berbeda dengan PR, setelah melampiaskan amarahnya, partisipan AT mengaku merasa terpuaskan. Menurutnya menyiksa adalah sesuatu yang menyenangkan. Sehabis menindak anggota atau juniornya dengan agresi fisik, AT mengaku sama sekali tidak merasa iba. Baginya hal tersebut pantas didapatkan sebagai konsekuensi dari pelanggaran.

Reaksi fisiologis yang dirasakan partisipan AT saat marah meliputi detak jantung yang intens atau disebut AT sebagai adrenaline blood rise, dan suhu tubuh naik (tanpa disadari), sementara untuk reaksi psikologis, AT merasa ingin menghancurkan sesuatu dibarengi dengan keinginan untuk berteriak, meledak, mengumpat atau berkata kasar. Selain itu ia juga merasa seperti ingin menghancurkan kepala orang, serta sensitif ketika diajak berkomunikasi, membuat dirinya mudah terpancing dan meledakledak. Meskipun demikian, semenjak terjerat kasus, AT selalu berusaha untuk lebih meredam emosinya dalam situasi-situasi genting. Namun tak jarang pula gagal ketika amarah yang dirasa sudah diambang batas. Cara yang dilakukan subjek AT untuk meredam amarah biasanya dengan meningkatkan spiritualitas melalui beristighfar dan membaca ayat suci. Sepengalaman kedua partisipan, semua tindakan yang dilakukan pasti memiliki esensi sekaligus memberikan efek jera (shock therapy) kepada 
anggota. Esensi dari tindakan-tindakan tersebut adalah agar para anggota menjadi lebih baik dan mengetahui kesalahan-kesalahan mereka, serta berupaya untuk tidak mengulanginya.

\section{Gambaran Stres dalam Proses Adaptasi}

Kedua partisipan sama-sama tidak mengalami stres akut selama proses adaptasi dari lingkungan AAL ke setting Dikko. Partisipan PR mengaku hanya mengalami stres ringan di awal Dikko, sekalipun sudah mendapat materi di perkuliahan juga testimoni dari senior. Stres tersebut dikarenakan sudah lama PR tidak terpapar kekerasan yang melebihi SOP di AAL, namun setelahnya menjadi terbiasa. Menurut PR ia dengan cepat terbiasa karena sebagai taruna Korps Marinir sudah terbiasa mendapatkan pengalaman yang mirip dengan Dikko, yakni saat mengikuti lattek Prayuda di tingkat II. Dalam proses adaptasi Dikko, di tahap awal PR menyesuaikan diri terlebih dahulu dengan mengikuti semua aturan yang ada. Setelah tiga sampai lima hari terlihat celahnya, baru ia mulai mencoba melanggar peraturan sedikit demi sedikit sebagai salah satu bentuk koping stres. Hal serupa juga dirasakan partisipan AT, ia mengaku tidak mengalami stres dalam proses adaptasi, hanya saja merasa sangat lelah di tahap awal Dikko, namun setelahnya menjadi terbiasa. Hal ini dikarenakan sebelumnya pernah mengikuti lattek Prayuda, dimana pada lattek itu para taruna diperkenalkan dengan hal-hal mendasar dari Pendidikan Komando. Selain itu, pemberian materi secara teoritis di kelas terkait Dikko selama perkuliahan serta testimoni dari senior membuat AT sudah berekspektasi tinggi dan lebih mempersiapkan fisik maupun mentalnya, sehingga ia tidak begitu kaget. Menurut AT, mereka sudah harus ber-mindset marinir, seorang prajurit lapangan yang pasti akan rentan terhadap keadaan keadaan darurat.

\section{Deskripsi Stres Selama Dikko}

Kondisi partisipan PR selama Dikko tertekan. Tertekan karena hampir semua kegiatan Dikko memiliki stressor dan tanggung jawab masing-masing, terlebih PR sebagai Komandan Peleton harus memastikan anggotanya dalam keadaan siap tempur. Tekanan berasal dari pendadakan serta kemungkinan perlengkapan anggota yang tidak lengkap atau hilang. Hilangnya senjata dikatakan sebagai salah satu kesalahan fatal dalam bertempur. Hal ini dikarenakan doktrin yang mengatakan jika seorang tentara kehilangan senjata dalam sebuah pertempuran, maka dirinya dianggap gugur. Selain itu kebersihan diri selama Dikko pun menjadi sangat minim dikarenakan tidak optimalnya waktu untuk membersihkan diri, sehingga tentunya sangat mempengaruhi penampilan seluruh peserta yang terbiasa rapi dan wangi. Kegiatan dengan stressor tertinggi selama Dikko ialah pendadakan. Pendadakan adalah suatu keadaan ketika keadaan secara tiba-tiba disimulasikan layaknya perang dengan adanya penjatuhan bom kecil. Saat pendadakan terjadi, para peserta Dikko harus segera mengambil perlengkapan perang. Selain dituntut untuk dapat berpikir dan bergerak cepat dalam tekanan, tugas seorang Danton untuk memastikan anggotanya lengkap, serta merupakan sebuah kewajiban pula untuk membawa perlengkapan perang dengan lengkap tanpa terkecuali. Tetapi kenyataannya banyak anggota yang teledor. Ada beberapa perlengkapan yang tertinggal, helm dan senjata pun hilang.

Dari semua tekanan yang dirasa selama Dikko, partisipan PR mengaku pernah merasa down dan sesekali berpikir untuk menyerah. Down yang dimaksud adalah perasaan jenuh akan disiksa. Ia pun menjelaskan hal ini terjadi di tahap awal Dikko yang dianggap terberat, dimana intensitas dan frekuensi penyiksaan lebih tinggi dibanding tahapan lainnya. Pada saat pembukaan Dikko, para taruna diperintahkan merayap, berguling kesana kemari, kemudian diminta untuk menanggalkan baju. Setiap hari dipukuli dan dicambuki, sehingga membuat peserta bingung sekaligus kaget hingga menyebabkan stres. Namun lama-lama PR mengaku bahwa tekanan yang dirasa perlahan berkurang. Bentuk penyiksaan yang paling tidak disukai PR ialah pencambukan. Selain menimbulkan rasa sakit yang luar biasa, pasalnya PR lebih jengkel ketika pencambukkan yang diterima dikarenakan kesalahan orang lain (anggota). 
Berbeda dengan PR, partisipan AT mengaku tidak begitu merasakan stres hebat selama Dikko. Ia mengatakan bahwa Dikko secara tidak langsung membangkitkan jiwa-jiwa militannya. Kegiatan paling memicu stres selama Dikko menurut AT adalah gerilya lawan gerilya, karena di tahap itu para taruna harus berpikir cepat tentang bagaimana cara menembus pertahanan musuh tanpa tertangkap. Pressure point ada pada perencanaan strategi serta taktik yang matang. Stres ini pernah selintas membuat AT berpikir untuk menyerah. Terkadang keadaan yang hectic bisa sangat sulit diatasi dan oleh karenanya membuat AT seperti ingin mati. Selain itu stres juga berasal dari ketakutan terbesar AT selama Dikko, yakni takut akan mati karena kelelahan atau tertembak. Pasalnya pada Dikko tiga tahun yang lalu, ada seorang peserta yang meninggal karena tertembak di kepalanya pada saat merayap di kegiatan doper dan jurko (jurit komando).

Strategi Koping Stres

Koping stres yang dilakukan partisipan PR adalah dengan sesekali menghubungi orang tua. Menurut PR, menghubungi orang tua, membuatnya semangat. Selain itu, ia kerap memotivasi diri sendiri agar tetap bersemangat. Motivasi tersebut berisi tentang bagaimana ia akan disambut di AAL sepulangnya dari Dikko, bagaimana orang-orang akan menaruh respect pada dirinya yang sudah berhasil menyelesaikan Dikko, kebanggaan untuk mengenakan baret ungu, serta keinginan untuk disegani taruna lain. Ia merasa bahwa orang tua adalah orang terpenting dalam hidupnya karena sampai saat ini hanya mereka yang selalu ada dan paling memahami dirinya. PR menyampaikan apa motivasinya untuk terus berjuang dan bertahan di Pendidikan Komando ini, ia ingin ketika ada cuti nanti, bisa berfoto bersama keluarga dengan mengenakan baret ungu, agar semua orang tahu bahwa subjek PR adalah anak yang membanggakan dan telah berhasil menjadi calon perwira marinir.

Dalam keadaan sulit, partisipan AT mengatasi stresnya dengan memandangi foto kekasihnya dan menelepon ketika ada waktu luang. Wajah cantik sang kekasih membuatnya lebih tenang dan meningkatkan motivasi untuk segera menyelesaikan pendidikan komando, sehingga bisa lekas bertemu dan melepas rindu. Menurut AT, kekasihnya merupakan orang yang sangat ia percaya dan orang yang membuatnya tetap bersemangat sekalipun situasi dan kondisi tidak mendukung. Selain ifu, makan juga menjadi salah satu coping stress partisipan AT, ia mengaku sering menghabiskan uangnya untuk memborong jajanan di warung-warung tempat beristirahat.

\section{Gambaran Risiko PTSD}

Peristiwa saat Dikko yang menurut partisipan PR cukup traumatis ia deskripsikan sebagai perasaan waspada yang kerap dirasakan karena seringnya dilakukan pendadakan. Perasaan itu muncul sejak Dikko berlangsung dan menetap selama 2-3 hari pasca kepulangan Dikko. Subjek PR menceritakan bahwa rasa waspada itu ada karena perannya sebagai pemimpin, dimana ia harus brtanggung jawab atas anggotanya dan memastikan perlengkapan anggota lengkap serta siap tempur. Hal ini pula yang menyebabkan PR mengalami gangguan tidur selama Dikko, dirinya kerap terbangun karena rasa waswas tersebut menghantui sepanjang malam. Dikko bukanlah pengalaman menyenangkan dan memiliki konsekuensi tersendiri yang harus diterima pesertanya. Tentunya Dikko akan berdampak secara fisik maupun psikologis. Setiap hukuman yang diterima selama Dikko meninggalkan bekas luka di tubuhnya, Bekas luka yang dimiliki PR beragam, tergantung dari tingkat keparahan teguran fisik yang diberikan. Jika pecutan yang dilakukan cukup kencang dengan frekuensi yang sering, maka bisa memar kebiruan hingga berdarah, namun jika ringan, maka hanya akan berbekas kemerahan.

Bagi PR, Dikko tidak begitu memberikan efek negatif yang signifikan terhadap mentalnya, meskipun ia sempat melaporkan bahwa enam bulan pasca Dikko, setiap kali mendengar suara ledakan, ia langsung 
berkilas balik (flashback) akan pengalaman Dikko yang tidak menyenangkan. Namun kilas balik tersebut tanpa diikuti gangguan-gangguan lain seperti kesulitan tidur, kecemasan yang intens, ataupun kesulitan bernapas. PR merasa mendapatkan cukup banyak perubahan positif yang ia rasakan pasca kembali dari Dikko. Ia menjadi lebih berani dalam mengambil keputusan, memahami teknik decision making yang tepat, lebih berpikir panjang sebelum bertindak, dan belajar berempati terhadap orang lain.

Cukup berbeda dari PR, partisipan AT merasa tidak ada peristiwa traumatis yang dialami selama Dikko, melainkan hanyalah peristiwa menyeramkan terkait makhluk astral yang diakui sempat membuat dirinya paranoid selama beberapa hari. Bahkan untuk sekelas Dikko yang setiap harinya dipenuhi siksaan, AT sama sekali tidak merasakan trauma, hal ini karena ia sudah terbiasa dengan hal-hal seperti itu sejak kecil. Partisipan AT mengatakan dampak fisiologis Dikko berupa luka-luka di tubuh dan cedera ringan. Luka terparah disebut berada pada punggung AT yang berupa bekas pecutan dari selang yang menyayat kulitnya hingga berdarah. Cedera ringan yang dialami adalah terkilirnya pergelangan kaki. Sementara untuk dampak psikologis, pada awalnya AT mengaku tidak merasakan dampak negatif dari Dikko, melainkan menurutnya Dikko melatih mental untuk menahan rasa sakit juga mengasah kemampuan memimpin dalam tekanan. Namun enam bulan pasca Dikko, AT melaporkan bahwa ia kerap merasa cemas, ketakutan, dan berkilas balik (flashback) hingga kesulitan bernapas setiap kali mendengar suara ledakan meriam.

\section{DISKUSI}

\section{Penyebab Anger Issues}

Individu yang menekan amarah (suppressed anger) diyakini menyangkal perasaan marah yang kuat, baik kepada diri sendiri maupun orang lain, meskipun emosi tersebut dapat terungkap melalui perubahan fisiologis dan perilaku, seperti gerak tubuh atau ucapan (Burns dkk., 1999). Emosi seperti kemarahan tidak akan hilang jika diabaikan. Emosi tersebut hanya akan menjadi lebih kuat dan dapat menyebabkan masalah yang parah. Studi menunjukkan bahwa perilaku marah dan agresif yang tidak dicegah atau segera ditangani pada akhirnya dapat menyebabkan perubahan pada otak yang akan menurunkan produksi serotonin dan meningkatkan kemungkinan perilaku marah dan agresif di kemudian hari (Society for Neuroscience, 2007 dalam Hendricks, 2013). Pembahasan lain mengenai penyebab anger issues dan perilaku agresif partisipan PR adalah karena perilaku tersebut merupakan hasil belajar dan penguatan (reinforcement). Melalui sudut pandang behavioristik, perilaku subjek dapat dijelaskan menggunakan Social Learning Theory. Teori ini didasarkan pada gagasan bahwa individu belajar dari interaksi dengan orang lain dalam konteks sosial. Secara terpisah, dengan mengamati perilaku orang lain, individu mengembangkan perilaku serupa. Setelah mengamati perilaku orang lain, individu mengasimilasi dan meniru perilaku tersebut, terutama jika pengalaman pengamatan mereka positif atau termasuk penerimaan reward yang terkait dengan perilaku yang diamati.

Ada tiga prinsip social learning theory, yaitu observasi, imitasi, dan modeling. Partisipan PR mengamati perilaku agresif senior-seniornya di AAL (melalui model langsung yang melibatkan individu aktual menunjukkan atau memerankan perilaku) yang mendapat respon positif dari lingkungan, kemudian ia berintensi untuk mengimitasi perilaku tersebut dengan harapan mendapatkan reward dan respon positif yang sama. Menurut Bandura (dalam Carole \& Carol, 2007), imitasi adalah perilaku yang dihasilkan ketika seseorang melihat model atau orang lain melakukan sesuatu dalam cara tertentu dan mendapatkan konsekuensi dari perilaku tersebut. Penguatan perilaku juga menjadi salah satu faktor 
yang berkontribusi dalam pembentukan anger issues jika dianalisis menggunakan operant conditioning yang didasarkan pada Thorndike's Law of Effect. Perilaku yang diperkuat cenderung diulangi (strengthened); perilaku yang tidak diperkuat cenderung mati atau dimusnahkan (weakened). Jenis respons atau operan yang diterima oleh partisipan $\mathrm{PR}$ ialah positive reinforcement dan negative reinforcement.

Penguatan negatif dilakukan oleh senior apabila PR tidak memenuhi kriteria minimal seorang Poltar. Seperti contoh, jika banyak didapati junior yang melanggar peraturan atau tidak beratribut lengkap, maka partisipan PR akan ditindak secara fisik baik dengan cambukan, tamparan, atau sikap-sikap. Selanjutnya PR akan lebih memperhatikan dan mendisiplinkan para junior untuk menghindari tindakan, sehingga PR memperkuat perilaku tegas, agresif, dan disiplinnya. Contoh kedua, penguatan positif ditunjukkan ketika setiap saat PR berperilaku agresif baik secara fisik maupun verbal kepada junior-juniornya, ia mendapatkan pujian dan afirmasi positif dari para senior serta reputasi yang baik. Hal ini membuat subjek PR senang dan berintensi untuk terus meningkatkan perilakunya tersebut.

Partisipan AT memiliki latar belakang penyebab anger issues yang berbeda. Ia menceritakan bahwa pernah menerima banyak kekerasan fisik maupun verbal dari sang Ayah sejak usia balita hingga remaja. Secara khusus, penganiayaan masa kanak-kanak menyumbang 15\% dari varian dalam agresi pada sampel yang didiagnosis dengan IED, serta riwayat keluarga dengan anger attack dapat meningkatkan risiko kekerasan fisik (Ahmed dkk, 2010 dalam Fernandez \& Johnson, 2016). Laki-laki dengan riwayat kekerasan fisik pada masa kanak-kanak secara signifikan lebih mungkin untuk terlibat dalam perilaku agresif dan antisosial daripada mereka yang tidak memiliki riwayat tersebut (Duncan dkk., 1996). Diakui oleh subjek bahwa kekerasan yang ia terima di masa kanak menjadi penyebab dirinya memiliki kepribadian temperamental. Dengan kata lain salah satu faktor penyebab anger issues ialah karena adanya pengalaman trauma masa kanak yang berkaitan dengan kekerasan dalam pengasuhan yang kemudian diikuti dengan proses imitasi atau hasil belajar, serta permasalahan kelekatan (attachment).

Menurut teori Vygotsky, anak-anak mengembangkan cara berpikir dan pemahaman utamanya melalui interaksi sosial (Santrock, 2012). Perkembangan kognitif anak-anak bergantung pada instrumen yang disediakan oleh masyarakat, dan pikiran mereka dibentuk oleh konteks budaya di tempat mereka tumbuh (Gredler, 2008; Holzman, 2009 dalam Santrock, 2012). Berkiblat pada teori Vygotsky, pemrosesan informasi, baik informasi positif maupun negatif dilakukan melalui interaksi, sehingga sangat memungkinkan apabila partisipan AT mempelajari perilaku agresif dari interaksi sehari-hari dengan sang Ayah. Sebagai anak kedua dari empat bersaudara, partisipan AT tidak sepenuhnya mendapatkan perhatian dari kedua orang tua. Hal ini berkaitan dengan kelekatan (attachment) serta hubungan interpersonal antara partisipan dengan orang tua yang kurang baik, sehingga menurut Ainsworth (1977 dalam Carr, 1999) dapat dikategorikan sebagai kelekatan anxious-ambivalent (insecure).

Ayah AT sering menghukum dengan kekerasan seperti memecuti dengan ikat pinggang, memukuli dengan sapu, menjambak, membantingnya ke pintu, dan menghantamkan kepala AT ke pintu berkalikali. Ibunda partisipan diceritakan jarang menolong ataupun membela, serta cenderung berpihak kepada sang Ayah. Deskripsi perilaku Ibunda AT sangat menggambarkan ciri kelekatan anxiousambivalent, dimana pada beberapa kesempatan orang tua menanggapi dengan menghibur anak namun pada kesempatan lain mengabaikan. Akhirnya anak cenderung untuk terus terlibat dalam perilaku pencarian kedekatan intensif (Belsky dan Nezworski, 1988 dalam Carr, 1999). Sementara deskripsi perilaku Ayah AT menunjukkan tipe kelekatan anxious-avoidant yang dicirikan sebagai penghindaran. Anak menolak kedekatan dengan caregiver setelah perpisahan. Mereka tidak kembali ke pengasuh 
(Ayah) setelah berpisah dan tidak menunjukkan kecemasan atau kondisi tertekan ketika ditinggal oleh pengasuh.

Diketahui anak dengan tipe kelekatan anxious-ambivalent dan anxious-avoidant berisiko mengalami kesulitan psikologis. Kelekatan anxious-avoidant terkadang merupakan hasil dari kekerasan atau pengabaian. Selain itu kekerasan fisik, seksual, dan emosional di masa kanak-kanak dapat membuat anak rentan untuk mengembangkan masalah emosional dan perilaku di kemudian hari (Briere dkk., 1996 dalam Carr, 1999). Serangan fisik dari orang yang kepadanya anak mencari cinta, pengasuhan, dan perlindungan merupakan trauma psikis yang sangat besar (Martin \& Rodeheffer, 1976). Mengaitkan dengan social learning theory, hal ini cukup dapat menjelaskan bagaimana awal mula partisipan AT bisa mempelajari perilaku agresif dan bagaimana mengekspresikan kemarahan. Sebuah studi sebelumnya, dirancang untuk menjelaskan fenomena identifikasi dalam hal pembelajaran insidental, menunjukkan bahwa anak-anak dengan mudah meniru perilaku yang ditunjukkan oleh model dewasa dengan kehadiran model tersebut (Bandura \& Huston, 1961 dalam Bandura dkk., 1961).

Terakhir, penyebab anger issues adalah penguatan atau reinforcement dan proses imitasi perilaku. Partisipan AT sudah mendapatkan modeling yang agresif sejak usia dini. Ditambah penguatan yang ada di AAL melalui doktrinisasi, senior, dan para pengasuh, dimana hal tersebut seakan-akan membenarkan perilaku AT. Pembahasan melalui sudut pandang social learning theory, pada awalnya partisipan AT melakukan observasi atau belajar dan meniru perilaku yang telah diamati pada orang lain, yakni ayahnya sebagai model langsung. Selanjutnya dalam proses imitasi, anak akan melihat orang tuanya sebagai figur utama yang layak ditiru sebelum meniru orang lain. Perilaku yang diimitasi menurut Soekanto (2005 dalam Arif, 2005) dapat berwujud penampilan (performance), sikap (attitude), tingkah laku (behavior), dan gaya hidup (life style). Berdasarkan hal ini, agresi juga dapat dipelajari melalui modeling. Selain karena hasil belajar, individu dengan trait anger yang tinggi juga menjadi salah satu faktor risiko dari anger issues. Trait merupakan disposisi kepribadian yang penting dan bersifat semi permanen. Kepribadian manusia menurut Eysenck dipengaruhi oleh faktor herediter dan lingkungan.

\section{Gambaran Anger Issues Selama Dikko}

Anggota, sebagai sumber kemarahan selama Dikko sering dirasa menyepelekan dan bersikap kurang ajar serta terkesan tidak menghargai Danton sebagai pimpinan. Selain anggota, partisipan PR juga kesal karena lelah selalu ditegur oleh pelatih dengan kesalahan-kesalahan kecil yang sama setiap harinya, seakan-akan para anggota tidak pernah mengerti dan belajar dari kesalahan yang diperbuat. Penjabaran data di atas sesuai dengan perspektif evolusi yang mengatakan seseorang merasa marah ketika sulit mencapai tujuan penting karena halangan yang disebabkan oleh pihak luar (Kashdan dkk., 2015). Partisipan PR dan AT kerap merasa kesal dan marah kepada anggota-anggotanya karena secara tidak langsung para anggota menghambat PR dan AT untuk mencapai tujuan mereka sebagai pimpinan, yakni menciptakan anggota peleton yang patuh dan sigap, sehingga bebas dari teguran dan hukuman dari pelatih.

Kemarahan juga dapat ditimbulkan oleh ketidaknyamanan fisik (Berkowitz, 1993b; Hatch dkk., 1992 dalam Kashdan dkk., 2015), yang memvalidasi klaim bahwa "rasa sakit adalah penyebab langsung dari kemarahan" (Izard, 1991 dalam Kashdan dkk., 2015). Sejak hari pertama Dikko, kedua partisipan sudah menerima agresi fisik dari para pelatih yang memberikan rasa nyeri tidak tertahankan pada tubuh, baik karena kesalahan sendiri, maupun karena kesalahan para anggota. Oleh karena itu PR dan AT merasa kesal karena harus menanggung kesalahan-kesalahan anggotanya. Partisipan PR dan AT memiliki cara yang sama dalam menyikapi kemarahan dan cara tersebut tak lain adalah dengan menggunakan 
teguran fisik. Teguran fisik tersebut antara lain pukulan, tamparan, serta gertakan-gertakan verbal lainnya. Tindakan tersebut dilakukan dengan tangan kosong, tanpa bantuan alat.

Sebagaimana didefinisikan dalam psikologi sosial, agresi adalah setiap perilaku yang ditujukan kepada individu lain yang dilakukan dengan niatan menyebabkan kerugian, di mana pelaku harus percaya bahwa perilaku tersebut akan merugikan target, dan akhirnya target termotivasi untuk menghindari perilaku tersebut (Baron dan Richardson, 1994; Anderson dan Bushman, 2002 dalam Gallaway, 2012). Tujuan agresi sesuai dengan tujuan kedua subjek ketika melakukan teguran fisik, yakni untuk memberikan shock therapy atau efek jera kepada anggota. Gaya respons kemarahan yang ditunjukkan oleh kedua partisipan menurut Spielberger (1988) ialah anger-out, yaitu kemarahan yang diekspresikan terhadap orang lain. Orang yang memiliki anger-out tinggi, sering kali menunjukkan amarah mereka melalui perilaku verbal atau fisik yang agresif (Whiteside \& Abramowitz, 2005). Selain itu adapun respon berteriak, memukul benda, dan berkelahi (Linden dkk., 2003 dalam Kerby dkk., 2003).

\section{Gambaran Stres dalam Proses Adaptasi}

Risiko stres akut pada kedua partisipan dalam menghadapi perubahan dan dalam proses adaptasi sangat minim. Hal ini dikarenakan sebelumnya mereka sudah diperkenalkan dengan hal hal mendasar dari Pendidikan Komando pada lattek Prayuda saat masih berpangkat Sersan. Selain itu, pemberian materi Dikko di kelas perkuliahan dan testimoni dari senior pun telah membuat kedua partisipan berekspektasi tinggi tentang Dikko, sehingga mereka tidak lagi terkejut dan sudah sangat mempersiapkan diri. Kebugaran jasmani jelas mempengaruhi kemampuan individu untuk mengelola dan beradaptasi dengan baik terhadap penyebab stres. Tingkat kebugaran fisik yang tinggi sebelum memasuki pertempuran dasar dan pelatihan militer dikaitkan dengan penurunan respons stres dan peningkatan outcome psikologis tentara (Soutwick \& Carny, 2012; Nindl dkk., 2018). Kebugaran jasmani dalam konteks ini dapat berasal dari latihan keseharian kedua partisipan di AAL menjelang Dikko dan lattek terdahulu, seperti Prayuda.

Resiliensi adalah kemampuan untuk mempertahankan fungsi psikologis dan fisiologis normal di hadapan stres dan trauma yang tinggi (Wu dkk., 2013 dalam Nindl dkk., 2018). Resiliensi awalnya ditanamkan dalam diri tentara melalui pelatihan dan persiapan yang bertujuan untuk meningkatkan toleransi fisiologis terhadap stres (Nindl dkk., 2018). Mengingat respons terhadap stresor psikologis yang sama dapat sangat bervariasi tiap individu, resiliensi dianggap sebagai trait individual. Manusia telah terbukti sebagai spesies yang sangat mudah beradaptasi. Melalui adaptasi perilaku dan lingkungan pelatihan, resiliensi berpotensi ditanamkan pada prajurit (Nindl dkk., 2018). Beberapa penelitian menyelidiki pengaruh pelatihan militer terhadap faktor psikologis dan kepribadian, seperti penelitian yang dilakukan oleh Sadeghinia yang menunjukkan bahwa masa pelatihan militer mempengaruhi kesehatan psikologis dan meningkatkan kesehatan mental (Sadeghinia, 2006 dalam Maleki dkk., 2012).

Pemahaman di atas kurang lebihnya dapat menjelaskan mengapa stres yang dialami subjek PR dalam proses adaptasi tidaklah akut. Selain karena kebugaran fisik yang tinggi, PR memiliki resiliensi yang stabil, baik dari lingkungan sosial (kebersamaan rekan satu letting), maupun familial (dukungan keluarga). Berbagai macam pelatihan yang dijalani sebelum Dikko juga dapat meningkatkan kesehatan mental dan resiliensi taruna.

\section{Deskripsi Stres Selama Dikko}

Aspek dramatis dari pertempuran telah ditetapkan sebagai pemicu stres psikologis. Penelitian terbaru telah menetapkan bahwa pertempuran dengan paparan korban yang berat, penempatan di zona perang, 
dan mobilisasi unit cadangan, semuanya berkorelasi dengan tingkat tekanan psikologis yang lebih tinggi (Solomon, 1993 dalam Pflanz \& Sonnek, 2002). Tampaknya diasumsikan bahwa tekanan kehidupan militer disebabkan oleh hal-hal seperti penempatan, pertempuran, dan ancaman cedera tubuh (Pflanz \& Sonnek, 2002).

\section{Strategi Koping Stres}

Strategi koping yang digunakan partisipan PR dalam mengelola stres selama Dikko ialah emotionfocused coping (EFC) yang bertujuan mengatur emosi yang timbul sebagai akibat dari pertemuan yang penuh tekanan (Lazarus \& Folkman, 1984), dan solution-focused approach. EFC umumnya digambarkan sebagai pengerahan efek adaptif jangka pendek ketika penilaian (appraisal) menghasilkan tekanan emosional yang intens, ketika stres dinilai tak terkendali, dan ketika sumber daya yang ada tidak cukup untuk mendukung strategi PFC. Dari perspektif yang berbeda, pemikiran solution-focused berpendapat bahwa individu harus menghabiskan sebagian besar waktu mengajukan pertanyaan yang memperoleh ide tentang cara terbaik untuk mencapai tujuan mereka, daripada mengajukan pertanyaan yang mengeksplorasi kausalitas atau emosi terkait masalah (Szabo \& Meier, 2009 dalam Grant \& Gerrard, 2019). Teori yang mendasari dalam konteks ini secara tidak langsung mengatakan bahwa seseorang tidak perlu mengetahui etiologi suatu masalah untuk dapat membangun solusi dan bergerak menuju pencapaian tujuan (Grant \& Gerrard, 2019).

Menurut PR, menghubungi orang tua membuat dirinya semangat. Selain menghubungi orang tua, PR kerap memotivasi diri sendiri agar tetap bersemangat. Hal ini sesuai dengan prinsip EFC, yaitu koping yang berkonsentrasi pada meminimalkan hasil emosional dari masalah dengan memberikan afirmasi positif. Keinginan mendapat respect dan membanggakan orang tua dikatakan sebagai salah satu goals atau tujuan partisipan PR. Hal ini sesuai dengan prinsip pendekatan solution-focused, yakni memperoleh ide tentang cara terbaik untuk mencapai tujuan. Salah satu alasan bahwa pendekatan yang berfokus pada solusi lebih efektif, adalah karena mengajukan pertanyaan yang berfokus pada solusi memunculkan sense of agency atau kesadaran subyektif untuk mengendalikan tindakan atas kehendak sendiri, dan cara berpikir yang kritis (Snyder, 2002 dalam Grant \& Gerrard, 2019). Ini adalah cara berpikir yang berorientasi pada tujuan yang meningkatkan motivasi untuk mengejar tujuan, meningkatkan keyakinan seseorang pada kapasitas untuk mencapai tujuan tersebut, serta mendorong pengembangan cara untuk mencapai tujuan (Snyder dkk, 2002 dalam Grant \& Gerrard, 2019).

Subjek AT mendeskripsikan strategi kopingnya selama Dikko adalah dengan memandangi foto kekasih dan meneleponnya ketika ada waktu luang. Menurut subjek, wajah cantik sang kekasih membuatnya lebih tenang dan meningkatkan motivasi untuk segera menyelesaikan Dikko sehingga bisa lekas bertemu dan melepas rindu. Dari deskripsi tersebut, strategi coping yang digunakan subjek AT adalah emotion-focused coping (EFC), yakni berkonsentrasi pada meminimalkan hasil (outcome) emosional dari masalah.

\section{Gambaran Risiko PTSD}

Berdasarkan gambaran situasi dan kondisi, pastinya sebagai sorang tentara yang rentan terpapar pertempuran memiliki risiko PTSD. Gangguan stres pascatrauma (PTSD) dapat berkembang setelah seseorang menyaksikan atau mengalami peristiwa traumatis, seperti bencana alam, pertempuran, atau serangan pribadi yang disertai kekerasan (Phillips dkk., 2010). Beberapa bukti menunjukkan bahwa dalam subset anggota tentara yang kembali, gejala stres pasca trauma (PTS) terus meningkat dan mengalami keparahan selama beberapa bulan dan tahun setelah kembali dari medan pertempuran (Grieger dkk., 2003 dalam Orcutt dkk., 2004). 
Di antara anggota militer, paparan pertempuran dilaporkan sebagai prediktor terkuat dari PTSD (Phillips dkk., 2010). Terlepas dari peristiwa traumatis itu sendiri, faktor risiko berkembangnya PTSD diantara lain usia yang relatif belia saat terpapar trauma, status sosial ekonomi yang rendah, riwayat penyakit kejiwaan dalam keluarga, penyerangan sebelumnya, kesulitan di masa kanak-kanak, jenis kelamin perempuan, ras minoritas, dan kurangnya dukungan sosial (Phillips dkk., 2010). Namun ada pula faktor protektif dari PTSD yang dapat berperan dalam meminimalisasi risiko seseorang terpapar PTSD, yaitu resiliensi yang baik. Resiliensi yang baik dapat ditanamkan sejak masa kanak, melalui: personal resource (efikasi diri atau optimisme yang tinggi), familial resource (dukungan orang tua, pengasuhan anak yang otoritatif, dan iklim atau kohesi keluarga yang baik), dan social resource (ketersediaan dukungan sosial di luar keluarga inti, seperti teman atau guru, hubungan pertemanan di luar).

Diketahui PR memiliki familial resource yang tercukupi, yakni berupa dukungan orang tua, pola pengasuhan anak yang baik, otoritatif, dan suportif, sehingga partisipan PR memiliki resiliensi dan koping stres yang baik. Hal ini dapat meminimalisasi kemungkinan PR terpapar gangguan mental serta disfungsi psikologis. Berdasarkan pengakuan PR, ia hanya merasakan "perasaan waspada" dalam hitungan hari saja, hal ini menggugurkan penegakkan diagnosis dari PTSD yang dimana sesuai Kriteria F mengatakan "Durasi gangguan (kriteria B, C, D, dan E) lebih dari satu bulan."

Gambaran situasi dan kondisi partisipan AT memenuhi beberapa faktor risiko PTSD, antara lain usia yang relatif belia saat terpapar trauma, riwayat kekerasan sebelumnya, dan kurangnya familial resource. Beberapa bulan setelah Dikko, AT memberikan self-report bahwa dirinya kerap merasa cemas, kesulitan bernafas, dan mengalami episode flashback setiap kali mendengar suara ledakan, dimana kondisi ini merupakan salah satu kriteria diagnostik dari Posttraumatic Stress Disorder. Hal ini baru ia rasakan ketika tengah mengikuti Lattek Suroyudho selama 12 hari di kota Malang terhitung sejak awal bulan Maret. Menurut DSM-V (2013), kilas balik (flashback) merupakan salah satu kriteria diagnostik dari PTSD. Tetapi diakui partisipan AT, bahwa kilas balik tersebut tidak intens, dalam arti hanya hadir ketika stressor muncul dan tidak diikuti dengan gangguan lain seperti sulit tidur, kecemasan, ataupun kesulitan bernapas.

\section{SIMPULAN}

Penyebab anger issues dapat berawal dari kebiasaan memendam suatu permasalahan dan membiarkan masalah tersebut menumpuk tanpa tersalurkan dengan baik (suppressed anger). Selain itu, adanya riwayat kekerasan fisik pada masa kanak dan masalah kelekatan juga menjadi faktor risiko. Persamaan kedua partispan ialah anger issues sama sama hasil belajar dan penguatan (reinforcement) dari lingkungan sekitar, serta karena keduanya memiliki trait anger yang tinggi sebagai faktor risiko dari anger issues. Gaya respons kemarahan yang ditunjukkan oleh kedua partisipan ialah anger-out, yaitu kemarahan yang diekspresikan terhadap orang lain. Kemarahan selama Dikko berasal dari perilaku anggota dan stres. Tekanan selama Dikko berasal dari pelatih, materi, pendadakan, serta tanggung jawab sebagai komandan peleton. Strategi koping yang digunakan dalam mengelola stres ialah emotionfocused coping (EFC) dan solution-focused approach yang bertujuan mengatur emosi yang timbul sebagai akibat dari tekanan dan perumusan solusi untuk mencapai tujuan dalam situasi stres. Berdasarkan gambaran situasi dan kondisi, pastinya sebagai seorang tentara yang rentan terpapar pertempuran, memiliki risiko PTSD. Namun ada pula faktor protektif dari PTSD yang dapat berperan dalam meminimalisasi risiko seseorang terpapar PTSD, yaitu resiliensi yang baik. Partisipan PR memiliki 
familial resource yang stabil, sementara partisipan AT tidak. AT memenuhi beberapa faktor risiko PTSD, yaitu riwayat trauma sebelumnya dan usia yang relatif belia saat terpapar trauma.

\section{UCAPAN TERIMAKASIH}

Terima kasih kepada Tuhan Yang Maha Esa, Allah SWT, karena berkat karunia dan kasih sayang-Nya penulis dapat sampai berada pada titik ini dan bisa menyelesaikan tugas akhir penentu kelulusan. Penyusunan karya ini tidak terlepas dari bantuan, bimbingan, juga dukungan berbagai pihak. Dalam kesempatan ini penulis ingin menyampaikan terima kasih kepada Dekan Fakultas Psikologi Universitas Airlangga, dosen pembimbing skripsi, kedua partisipan penelitan, orang tua dan kakak penulis yang setia mendoakan, serta teman-teman seperjuangan atas semangat dan dukungannya.

\section{DEKLARASI POTENSI TERJADINYA KONFLIK KEPENTINGAN}

Almira Nadya Yasmine dan Afif Kurniawan tidak bekerja, menjadi konsultan, memiliki saham, atau menerima dana dari perusahaan atau organisasi manapun yang mungkin akan mengambil untung dari diterbitkannya naskah ini.

\section{PUST AKA ACUAN}

Admin Puspen TNI. (2020, April 16). Gubernur AAL Lepas18 Taruna Korps Marinir Ikuti Pendidikan Komando. Retrieved from Puspen TNI: https://tni.mil.id/view-175508-gubernur-aal-lepas18taruna-korps-marinir-ikuti-pendidikan-komando.html

Akademi Angkatan Laut. (2019). Kualifikasi Lulusan. Retrieved from Akademi Angkatan Laut: http://www.aal.ac.id/kualifikasi/

Arif , R. (2005). Sosiologi. Jakarta: Raja Grafindo Persada.

Atriana, R., \& Pratama, F. (2019, February 12). 13 Taruna Akpol Diberhentikan karena Kasus Penganiayaan Terhadap Junior. Retrieved from detikNews: https://news.detik.com/berita/d4424972/13-taruna-akpol-diberhentikan-karena-kasus-penganiayaan-terhadap-junior

Bandura , A., Ross, D., \& Ross, S. (1961). Transmission of Aggression Through Imitation of Aggressive Models. First published in Journal of Abnormal and Social Psychology,, 63, 575-582.

Bogg, J., \& Cooper, C. (1995). Job Satisfaction, Mental Health, and Occupational Stress Among Senior Civil Servants. Human Relations, 48, 327-341.

Boyatzis, R. (1998). Transforming Qualitative Information: Thematic Analysis. Sage Publication, Inc.

Burns , J., Evon , D., \& Strain-Saloum, C. (1999). Repressed Anger and Patterns of Cardiovascular, SelfReport and Behavioral Responses. Journal of Psychosomatic Research, 47(6), 569-581.

Carole, \& Carol. (2007). Psikologi Edisi 9. Jakarta: Erlangga. 
Carr, A. (1999). The Handbook of Child and Adolescent Clinical Psychology : A Contextual Approach. London: Routledge.

Diagnostic and Statistical Manual of Mental Disorder V. (2013). Washington DC: American Psychiatric Association .

Dolan , C., \& Ender, M. (2008). The Coping Paradox: Work, Stress, and Coping in the U.S. Army. MILITARY PSYCHOLOGY, 20 : 151-169.

Duncan , R., Saunders , B., Kilpatrick , D., Hanson , R., \& Resnick, H. (1996). Childhood physical assault as a risk factor for PTSD, depression, and substance abuse: Findings from a national survey. American Journal of Orthopsychiatry, 66(3), 437-448.

Fernandez, E., \& Johnson, S. (2016). Anger In Psychological Disorders: Prevalence, Presentation, Etiology and Prognostic Implications. Clinical Psychology Review, 46, 124-135.

Gallaway, M., Fink, D., \& Millikan , A. (2012). Factors Associated With Physical Aggression Among US Army Soldiers. AGGRESSIVE BEHAVIOR, Volume 00, 1-11.

Grant, A., \& Gerrard, B. (2019). Comparing Problem-Focused, Solution-Focused and Combined ProblemFocused/Solution-Focused Coaching Approach: Solution-Focused Coaching Questions Mitigate The Negative Impact of Dysfunctional Attitudes. International Journal of Theory, Research and Practice, 1-17.

Gubernur Akademi Angkatan Laut. (2019). Peraturan Khusus Taruna (revised). Surabaya : Akademi Angkatan Laut.

Hendricks, L., Bore , S., Aslinia, D., \& Morris , G. (2013). The Effects of Anger on the Brain and Body. National Forum Journal of Counseling and Addiction, Vol. 2, No. 01.

Howells, K., \& Day, A. (2003). Readiness for Anger Management: Cinical and Theoretical Issues. Clinical Psychology Review, 23(2), 319-337.

Kashdan, T., Goodman, F., \& Mallard, T. (2015). What Triggers Anger in Everyday Life? Links to the Intensity, Control, and Regulation of These Emotions, and Personality Traits. Journal of Personality, 00:00.

Kerby, D., Brand, M., \& John, R. (2003). Anger Types and The Use of Cigarettes and Smokeless Tobacco among Native American Adolescents. Preventive Medicine, 37(5), 485-491.

Kodiklatal TNI AL. (2018, Februari 16). 352 Siswa Dikmata Kodiklatal, Ikuti Lintas Medan BanyuwangiSurabaya. Retrieved from Kodiklatal TNI AL: https://kodiklatal.tnial.mil.id/?hal=ShowBerita\&id=1577

Kodiklatal TNI AL. (2020, Desember 9). Dankodiklatal Tinjau Lattek Doper Rangkaian Dikko Angkatan Ke-165 Siswa Dikmata Marinir. Retrieved from Kodiklatal TNI AL: https://kodiklatal.tnial.mil.id/?hal=ShowBerita\&id=2922

Lazarus, R., \& Folkman , S. (1984). Stress, Appraisal, and Coping. New York: Springer. 
Legg, T. (2019, Februari 4). Do I Have Anger Issues? How to Identify and Treat an Angry Outlook. Retrieved from healthline: https://www.healthline.com/health/anger-issues

Maan Diong, S., Bishop, G., Enkelmann, H., Tong, E., Why, Y., Ang, J., \& Khader, M. (2005). Anger, Stress, Coping, Social Support and health: Modelling The Relationships. Psychology \& Health, 20(4), 467-495.

Macmanus, D., Rona, R., Dickson, \& Hannah. (2015). Aggressive and Violent Behavior Among Military Personnel Deployed to Iraq and Afghanistan: Prevalence and Link With Deployment and Combat Exposure. Epidemiologic Reviews, Vol. 37, Number 10.

Maleki , B., Sanei, S., Borhani, H., \& Ghavami , A. (2013). Effect of Military Training on Personality Traits of Military Students. Iranian Journal of Military Medicine,, Volume 13, Issue 4; 195-200.

Martin, H. P., \& Rodeheffer, M. A. (1976). The Psychological Impact of Abuse on Children. Journal of Pediatric Psychology, 1(2) 12-16.

Mekarisce, A. (2020). Teknik Pemeriksaan Keabsahan Data pada Penelitian Kualitatif di Bidang Kesehatan Masyarakat. Jurnal Ilmiah Kesehatan Masyarakat, Vol. 12 Edisi 3.

Nindl, B., Billing, D., Drain, J., Beckner , M., Grieves , J., Groeller, H., \& Friedl, K. (2018). Perspectives on Resilience For Military Readiness and Preparedness: Report of An International Military Physiology Roundtable. Journal of Science and Medicine in Sport.

Orcutt, H., Erickson, D., \& Wolfe, J. (2004). The course of PTSD symptoms among Gulf War veterans: A growth mixture modeling approach. Journal of Traumatic Stress, 17, 195-202.

Pflanz, S., \& Sonnek, S. (2002). Work Stress in the Military: Prevalence, Causes, and Relationship to Emotional Health. Military Medicine, 167(11), 877-882.

Phillips, C., Leardmann, C., Gumbs, G., \& Smith, B. (2010). Risk Factors for Posttraumatic Stress Disorder Among Deployed US Male Marines. BMC Psychiatry,, 10:52.

Poerwandari, E. (2005). Pendekatan Kualitatif dalam Penelitian Psikologi. Jakarta: Lembaga Pengembangan Sarana Pengukuran dan Pendidikan Psikologi.

Putra, M. B. (2019, Desember 27). Curi Barang dan Aniaya Junior, 2 Taruna Akademi Militer Diberhentikan Secara Tidak Hormat. Retrieved from Pikiran Rakyat: https://www.pikiranrakyat.com/nasional/pr-01328368/curi-barang-dan-aniaya-junior-2-taruna-akademi-militerdiberhentikan-secara-tidak-hormat

Putusan Terbaru Dilmil III-12 Surabaya. (2019, April 18). Retrieved from Direktori Putusan Pengadilan Militer III-12 Surabaya: http://putusan.dilmil-surabaya.go.id/putusanterbaru.html?sobi2Task=sobi2Details\&catid=21\&sobi2Id=1514

Santrock, J. (2012). Life Span Development 13th Edition. New York: Mc Graw - Hill.

Sharma , S., \& Sharma , M. (2012). Low Intensity Conflict Stress in Soldiers: Building Coping Skills and Resources. Psychology Study, 57(3): 260-268. 
Spielberger, C. (1988). Manual for the State-Trait Anger Expression Inventory (STAXI). Odessa, FL: Psychological Assessment Resources.

Veenstra , L., Bushman, B., \& Koole, S. (2018). The Facts on The Furious: A Brief Review of The Psychology of Trait Anger. Current Opinion in Psychology,, 19, 98-103.

Whiteside, S., \& Abramowitz, J. (2005). The Expression of Anger and Its Relationship to Symptoms and Cognitions In Obsessive-Compulsive Disorder. Depression and Anxiety, 21(3), 106-111.

Wilk , J., West, J., Duffy , F., Herrell, R., Rae, D., \& Hoge , C. (2013). Use of Evidence-Based Treatment for Posttraumatic Stress Disorder in Army Behavioral Healthcare. Psychiatry: Interpersonal and Biological Processes, 76(4), 336-348.

Wilkowski, B., \& Robinson, M. (2010). The Anatomy of Anger: An Integrative Cognitive Model of Trait Anger and Reactive Aggression. Journal of Personality, 78(1), 9-38. 